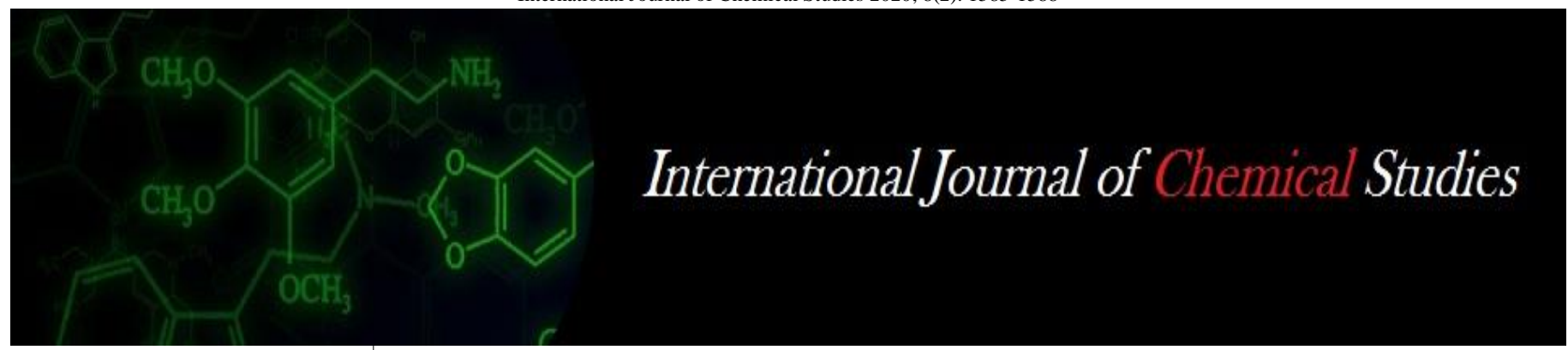

P-ISSN: 2349-8528

E-ISSN: 2321-4902

www.chemijournal.com

IJCS 2020; 8(2): 1585-1588

(C) 2020 IJCS

Received: 18-01-2020

Accepted: 22-02-2020

Katesiya Mahesh Keshabhai Department Agriculture

Entomology, Chimanbhai Patel

College of Agriculture,

Sardarkrushinagar Dantiwada

Agricultural University,

Sardarkrushinagar, Gujarat,

India

Dr. Babubhai Gobarbhai

Prajapati

Associate Research

Scientist, Department

Agriculture Entomology, Seed

Spices Research Station,

S.D.A.U., Jagudan, Gujarat,

India

Vijaykumar Bhikhabhai

Prajapati

Department Agriculture

Entomology, B. A. College of

Agriculture, Anand Agricultural

University, Anand, Gujarat,

India

Sanketkumar Mahendrabhai

Patel

Department Agriculture

Entomology, Chimanbhai Patel

College of Agriculture,

Sardarkrushinagar Dantiwada

Agricultural University,

Sardarkrushinagar, Gujarat,

India

Chandreshbhai Balwantbhai

Solanki

Department Agriculture

Entomology, Chimanbhai Patel

College of Agriculture,

Sardarkrushinagar Dantiwada

Agricultural University,

Sardarkrushinagar, Gujarat,

India

Corresponding Author:

Katesiya Mahesh Keshabhai

Department Agriculture

Entomology, Chimanbhai Patel

College of Agriculture,

Sardarkrushinagar Dantiwada

Agricultural University,

Sardarkrushinagar, Gujarat,

India

\section{Bio-efficacy of various bio-rationals against aphid, Aphis gossypii Gloverinfesting isabgul}

\author{
Katesiya Mahesh Keshabhai, Dr. Babubhai Gobarbhai Prajapati, \\ Vijaykumar Bhikhabhai Prajapati, Sanketkumar Mahendrabhai Patel \\ and Chandreshbhai Balwantbhai Solanki
}

DOI: https://doi.org/10.22271/chemi.2020.v8.i2x.8988

\begin{abstract}
An investigation was carried out during rabi, 2017-18 to evaluate the various bio-rationals against aphid, Aphis gossypii Glover in isabgul crop under field condition at S. D. A. U., Sardarkrushinagar, Dantiwada. The result of the field study revealed that, among the bio-rationals two sprays of Lecanicillium lecanii (1 $\left.\times 10^{9} \mathrm{cfu} / \mathrm{gm}\right)(40 \mathrm{~g} / 10 \mathrm{lit}$.) found most effective treatment and it was closely followed by treatments $L$. lecanii (40 g/10 lit.) followed by Azadirachtin $10000 \mathrm{ppm}(30 \mathrm{ml} / 10$ lit.) as well as L. lecanii (40 g/10 lit.) followed by Azadirachtin $1500 \mathrm{ppm}(40 \mathrm{ml} / 10$ lit.) was effective against aphid. The highest seed yield of isabgul $(895 \mathrm{~kg} / \mathrm{ha})$ was recorded in the treatment of $L$. lecanii $\left(1 \times 10^{9} \mathrm{cfu} / \mathrm{gm}\right)(40 \mathrm{~g} / 10 \mathrm{lit}$. $)$ followed by $L$. lecanii (40 g/10 lit.).Thus, from the overall results it can be concluded that Lecanicilliumlecanii $\left(1 \times 10^{9} \mathrm{cfu} / \mathrm{gm}\right)\left(40 \mathrm{~g} / 10\right.$ lit.) followed by Lecanicillium lecanii $\left(1 \times 10^{9} \mathrm{cfu} / \mathrm{gm}\right)(40$ $\mathrm{g} / 10$ lit.) Proved most effective for the management of aphid, A. gossypii in isabgul crop.The treatment of L.lecanii $\left(1 \times 10^{9} \mathrm{cfu} / \mathrm{gm}\right)(40 \mathrm{~g} / 10$ lit.) Followed by L. lecanii $(40 \mathrm{~g} / 10 \mathrm{lit}$.) had obtained the highest seed yield of isabgul $\left(895 \mathrm{kgha}^{-1}\right)$.
\end{abstract}

Keywords: Isabgul, isbgul aphid, aphis gossypii glover, bio-efficacy

\section{Introduction}

Isabgul (Plantagoovata Forsk.) is a medicinal plant that was originated from arid and semiarid zones and is used widely in traditional and industrial pharmacology. It belongs to order plantagenets which consist of only a single family: Plantaginaceae. These species either are annual or perennial herbs. About 10 species of Plantago are recorded in India. P. ovata is only the cultivated species of the country because of its bold seed. Indian P. ovata is preferred over European Plantagopsyllium and Plantagoindica (Trease and Evans, 1978). P. ovata is known to be grown as wild in warmer and drier parts of the Mediterranean region of India. Seeds and husks of isabgul are also used widely in pharmacology as laxatives. Interest in isabgul has risen primarily due to its use in high fiber breakfast cereals and from claims that, it is effective in reducing cholesterol. The World Health Organization (WHO) has estimated that more than 80 per cent of world population in developing countries depends primarily on herbal medicine for basic healthcare. International market of medicinal plants is over US \$ 60 billion per year. India ranks first in isabgul production (98\%) and the sole supplier of seeds and husk in the international market. India exports herbal materials and medicines to the tune of nearly 600 crores annually. India holds a monopoly in its production and trade in the world. Hence, isabgul is a major foreign exchange earner ( 30 million annually).

The seed husk is an age-old medicine in Ayurveda for the treatment of constipation. The husk derived from $P$. ovata, also referred to as isabgul orpsylliummucilloid. The husk absorbs water, increases moisture content in stool and swells up to give increased bulk in intestine which leads to solve the problem of constipation.

It is one of the important medicinal crops traditionally cultivated in north Saurashtra and Kachchh regions of Gujarat. South western Rajasthan, Haryana, Madhya Pradesh and Punjab are also produced small quantity of isabgul. In Gujarat during the year 2016-17, district-wise area and production under isabgul cultivation is 400ha and 360 M.T. in Ahmedabad, 1849 ha and 2311.25M.T. in Banaskantha, 100 ha and 95M.T. in Junagadh, 800ha and 760M.T. in Kheda, 10800ha and 11340M.T. in Kachchh, 23ha and 19M.T. in Mahisagar, 200ha and 
170M.T. in Mehsana, 100ha and 95M.T. in Morbi, 700ha and 735M.T. Patan, 600ha and570 M.T. Surendranagar (Anon., 2016-17). India holds monopoly in the production and export of Isabgul to the world market and about 80 to 90 per cent produce is mainly exported to U.S.A., West Germany, United Kingdom and France.

Isabgul is commercially grown as a rabi crop, which remains in the field for about four to five months. The most important component of isabgul is husk obtained from its seed. Isabgul husk is popularly known as "Sat Isabgul" in Indian market. In the successful production of isabgul crop, insect pests and diseases are of major limiting factors. Important insect pests infesting isabgul are aphid, Aphis gossypii Glover, seed beetle, Lasiodermaserricorne (Fabricius), white grub, Holotricheaconsanguinea Blanchard and termite, Odontotermesobesus Rambur (Reddy, 2009).

In-spite of regular occurrence of A. gossypii on isabgul crop in North Gujarat and South Rajasthan regions causing enormous economic losses, no any systemic research work has been carried out on various aspects of such an important pest of isabgul in Gujarat state. Keeping these points in view, to overcome lacunae and to develop an eco-friendly and effective pest management strategy, the present study was carried out with the following aspects.

\section{Materials and Methods}

A field experiment was carried out during rabi, 2017-18 at Agronomy Instructional Farm, Chimanbhai Patel College of Agriculture, Sardarkrushinagar Dantiwada Agricultural University, Sardarkrushinagar to find out the most effective bio-rational against aphid infesting isabgul. The isabgul variety Gujarat Isabgul 4 was sowned by line sowing method with a gross plot size of $4.0 \mathrm{~m} \times 3.0 \mathrm{~m}$ (spacing $30 \mathrm{~cm} \times 10 \mathrm{~cm})$. The trials were laid out in Randomized Block Design (RBD) with eight treatments and three replications. All the pre and post-sowing agronomical practices were adopted to raise the healthy crop. Each insecticide was applied by means of manually operated knapsack sprayer. First foliar spray was made at 1.5 aphid index and second spray was applied after 10 days of the first spray.

For recording the observation, five plants were selected randomly from each net plot. Observations on aphid population were recorded before and after 1, 3 and 7 days of application of different insecticides. Seed yield of isabgul was recorded. The data thus, obtained were statistically analyzed after suitable transformation.

Following aphid index given by Bank (1954) was fixed for estimating the population of aphid and the average aphid index was worked out by adopting following formula.

\section{Average aphid index $=\frac{0 \mathrm{~N}+1 \mathrm{~N}+2 \mathrm{~N}+3 \mathrm{~N}+4 \mathrm{~N}}{\text { Total number of plants observed }}$}

Where, 0, 1, 2, 3, 4are aphid index,

$\mathrm{N}=$ Number of plant showing respective aphid index.

Table 1: Aphid index

\begin{tabular}{|c|c|c|}
\hline \multicolumn{2}{|c|}{ Aphid index } & Particulars \\
\hline 0 & $:$ & Plant free from aphid \\
\hline 1 & $:$ & $\begin{array}{c}\text { Aphid present, but colonies did not build up. No } \\
\text { injury due to pest apparent on the plant }\end{array}$ \\
\hline 2 & $:$ & Small colonies of aphid were present \\
\hline 3 & $:$ & $\begin{array}{c}\text { Large colonies of aphid was present on tender } \\
\text { parts and show damage symptoms due to aphids }\end{array}$ \\
\hline 4 & $:$ & Entire plant was covered by aphids \\
\hline
\end{tabular}

Seed yield of isabgul was recorded from each net plot at harvest and yield data were converted into hectare basis.

\section{Results and Discussion \\ First spray \\ Before spray}

The results on aphid index prior to spray are summarised in table 1 . The results showed that there were non-significant differences in aphid index prior to first spray among different treatments indicated that the aphid population in isabgul crop was uniformly distributed in the whole experimental plot.

\section{First day after first spray}

The aphid index at first day after first spray revealed that the lowest population of aphid was recorded in Lecanicilliumlecanii $\left(1 \times 10^{9} \mathrm{cfu} / \mathrm{gm}\right)(40 \mathrm{~g} / 10 \mathrm{lit}$.) followed by L.lecanii (40g/10lit.) (2.21 aphid index) and it was proved to be the best effective treatment, however, it was remained at par with L. lecanii (40g/10lit.) followed by Azadirachtin 10000ppm (30ml/10lit.) (2.21 aphid index) and L. lecanii (40g/10lit.) followed by Azadirachtin 1500ppm (40ml/10lit.) (2.26aphid index), L. lecanii (40g/10lit.) followed by $B$. bassiana (40g/10lit.) had registered 2.48aphid index, $B$. bassiana (40g/10lit.) followed by $B$. bassiana $\left(1 \times 10^{9} \mathrm{cfu} / \mathrm{g}\right)$ (40g/10lit.) (2.38aphid index), the treatment of $B$. bassiana (40g/10lit.) followed by Azadirachtin 10000ppm (30ml/10lit.) (2.72aphid index), B. bassiana (40g/10lit.) followed by Azadirachtin 1500ppm (40ml/10lit.) (2.73aphid index). Untreated control plots had recorded 3.51aphid index and proved to be the least effective treatment among all the treatments under testing.

\section{Three days after first spray}

The results pertaining to aphid index at three days after first spray were revealed that all the bio-rationals remained significantly superior overuntreated control. The lowest population ofaphid was recorded in L. lecanii $\left(1 \times 10^{9} \mathrm{cfu} / \mathrm{g}\right)$ (40g/10lit.) followed by L. lecanii (40g/10lit.) (2.19 aphid index) and it was proved to be the most superior treatment over rest of the treatments, however, it was at par with $L$. lecanii (40g/10lit.) followed by Azadirachtin 10000ppm (30ml/10lit.) (2.17 aphid index) and L. lecanii (40g/10lit.) followed by Azadirachtin 1500ppm (40ml/10lit.) (2.21 aphid index), L. lecanii (40g/10lit.) followed by $B$. bassiana (40g/10lit.) had registered 2.41 aphid index, B. bassiana (40g/10lit.) followed by B. bassiana (40g/10lit.) (2.31 aphid index), B. bassiana (40g/10lit.) followed by Azadirachtin $10000 \mathrm{ppm}$ (30ml/10lit.) (2.69aphid index), B. bassiana (40g/10lit.) followed by Azadirachtin 1500ppm (40ml/10 lit.) (2.67 aphid index).The aphid population was remained higher in the plots of untreated control (3.53 aphid index) at three daysafter first spray.

\section{Seven days after first spray}

All the treatments remained significantly superior over untreated control with respect to aphid index at seven days after first spray. The lowest aphid index was recorded in $L$. lecanii $\left(1 \times 10^{9} \mathrm{cfu} / \mathrm{gm}\right)(40 \mathrm{~g} / 10$ lit.) followed by $L$. lecanii (40g/10lit.) (1.84 aphid index) and it was found to be the most superior treatment over rest of the treatments, however, it was remained at par with $L$. lecanii (40g/10lit.) (40g/10 lit.) followed by Azadirachtin 10000ppm (30ml/10lit.) (1.99 aphid index) and L. lecanii (40g/10lit.) followed by Azadirachtin $1500 \mathrm{ppm}$ (40ml/10 lit.) (2.04 aphid index), L. lecanii (40g/10lit.) followed by B. bassiana (40g/10lit.) Had 
registered 2.28 aphid index, B. bassiana $(40 \mathrm{~g} / 10$ lit.) followed by $B$. bassiana (40 g/10 lit.) (2.18aphid index), the treatment of $B$. bassiana (40 g/10 lit.) followed by Azadirachtin 10000ppm (30ml/10lit.) (2.53 aphid index), B. bassiana (40g/10lit.) followed by Azadirachtin 1500ppm (40ml/10lit.) (2.54aphid index).The highest aphid index was recorded in untreated control had recorded 3.56 aphid index at seven days after first spray.

\section{Second spray}

\section{First day after second spray}

The results (Table 2) pertaining to aphid index at first day after second spray were revealed that all the treatments remained significantly superior over untreated control. The lowest population of aphid was recorded in $L$. lecanii (40g/10lit.) (40g/10lit.) followed by L. lecanii (40g/10lit.) (40g/10lit.) (1.67 aphid index) and it was found to be the most superior treatment over rest of the treatments, however, it was statistically at par with L. lecanii (40g/10lit.) (40g/10lit.) followed by Azadirachtin 10000ppm (30ml/10lit.) (1.89 aphid index) and $L$. lecanii (40g/10lit.)(40g/10lit.) followed by Azadirachtin 1500ppm (40ml/10 lit.) (1.91 aphid index), $L$. lecanii (40g/10lit.) (40g/10lit.) followed by B. bassiana (40 g/10 lit.) (2.08 aphid index), B. bassiana (40g/10lit.)followed by $B$. bassiana (40g/10lit.)(2.04aphid index), the treatment of B. bassiana (40g/10lit.) followed by Azadirachtin 10000ppm (30ml/10lit.)(2.35aphid index). The treatment B. bassiana (40g/10lit.) followed by Azadirachtin 1500ppm (40ml/10lit.) had record 2.44 aphid index. The aphid population was remained higher in the plots of untreated control (3.58aphid index) at first day after second spray.

\section{Three days after second spray}

Looking to the aphid index at three days after second spray, the lowest population was recorded in L. lecanii (40g/10lit.) followed by $L$. lecanii (40g/10lit.) (1.14 aphid index) and it was found to be the most superior treatment over rest of the treatments, however, it was remained at par with L. lecanii (40g/10lit.) followed by Azadirachtin 10000ppm(30ml/10lit.) (1.26 aphid index) and $L$. lecanii (40g/10lit.)followed by Azadirachtin 1500ppm (40ml/10lit.) (1.47 aphid index), $L$. lecanii (40g/10lit.) followed by B. bassiana (40g/10lit.) had registered1.86 aphid index, B. bassiana (40g/10lit.) followed by $B$. bassiana (40g/10lit.) (1.85 aphid index), $B$. bassiana (40g/10lit.) followed by Azadirachtin 10000ppm

Table 2: Bio-efficacy of various bio-rationals against aphid, A. gossypii infesting isabgul

\begin{tabular}{|c|c|c|c|c|c|c|c|c|c|}
\hline \multirow{3}{*}{ Tr. No. } & \multirow{3}{*}{ Treatments } & \multicolumn{7}{|c|}{ Aphid index/ plant at different intervals of spray } & \multirow{3}{*}{$\begin{array}{c}\text { Seed yield } \\
\text { (Kg/ha) }\end{array}$} \\
\hline & & \multirow{2}{*}{$\begin{array}{l}\text { Before } \\
\text { spray }\end{array}$} & \multicolumn{3}{|c|}{$1^{\text {st }}$ Spray } & \multicolumn{3}{|c|}{$2^{\text {nd }}$ Spray } & \\
\hline & & & 1DAS & 3DAS & 7DAS & 1DAS & 3DAS & 7DAS & \\
\hline 1 & $\begin{array}{c}\text { L. lecanii }\left(1 \times 10^{9} \mathrm{cfu} / \mathrm{gm}\right)(40 \mathrm{~g} / 10 \text { lit.)followed by } \\
\text { Azadirachtin } 10000 \mathrm{ppm}(30 \mathrm{ml} / 10 \text { lit. })\end{array}$ & $\begin{array}{l}1.78^{*} \\
(2.67)\end{array}$ & $\begin{array}{l}1.65 * \mathrm{~b} \\
(2.21)\end{array}$ & $\begin{array}{l}1.63 * \mathrm{~b} \\
(2.17)\end{array}$ & $\begin{array}{l}1.58 * \mathrm{~b} \\
(1.99)\end{array}$ & $\begin{array}{c}1.55^{* b c} \\
(1.89)\end{array}$ & $\begin{array}{l}1.33^{* a} \\
(1.26)\end{array}$ & $\begin{array}{l}1.26^{* b} \\
(1.10)\end{array}$ & $827^{\mathrm{ab}}$ \\
\hline 2 & $\begin{array}{l}\text { L. lecanii }\left(1 \times 10^{9} \mathrm{cfu} / \mathrm{gm}\right)(40 \mathrm{~g} / 10 \text { lit.)followed by } \\
\text { Azadirachtin } 1500 \mathrm{ppm}(40 \mathrm{ml} / 10 \text { lit. })\end{array}$ & $\begin{array}{c}1.79 \\
(2.71)\end{array}$ & $\begin{array}{l}1.66^{\mathrm{b}} \\
(2.26)\end{array}$ & $\begin{array}{l}1.65^{\mathrm{b}} \\
(2.21)\end{array}$ & $\begin{array}{l}1.59^{\mathrm{b}} \\
(2.04)\end{array}$ & $\begin{array}{l}1.55^{\mathrm{bc}} \\
(1.91)\end{array}$ & $\begin{array}{r}1.40^{\mathrm{a}} \\
(1.47)\end{array}$ & $\begin{array}{l}1.29^{b} \\
(1.17)\end{array}$ & $814^{\mathrm{ab}}$ \\
\hline 3 & $\begin{array}{c}\text { B. bassiana }\left(1 \times 10^{9} \mathrm{cfu} / \mathrm{gm}\right)(40 \mathrm{~g} / 10 \text { lit. }) \text { followed } \\
\text { by Azadirachtin } 10000 \mathrm{ppm}(30 \mathrm{ml} / 10 \text { lit. })\end{array}$ & $\begin{array}{c}1.83 \\
(2.85)\end{array}$ & $\begin{array}{l}1.79^{\mathrm{ab}} \\
(2.72)\end{array}$ & $\begin{array}{l}1.79^{\mathrm{ab}} \\
(2.69)\end{array}$ & $\begin{array}{l}1.74^{\mathrm{b}} \\
(2.53) \\
\end{array}$ & $\begin{array}{l}1.69^{\mathrm{bc}} \\
(2.35)\end{array}$ & $\begin{array}{l}1.55^{\mathrm{b}} \\
(1.89) \\
\end{array}$ & $\begin{array}{r}1.45^{\mathrm{b}} \\
(1.61) \\
\end{array}$ & $710^{\mathrm{b}}$ \\
\hline 4 & $\begin{array}{c}\text { B. bassiana }\left(1 \times 10^{9} \mathrm{cfu} / \mathrm{gm}\right)(40 \mathrm{~g} / 10 \text { lit.)followed } \\
\text { by Azadirachtin } 1500 \mathrm{ppm}(40 \mathrm{ml} / 10 \text { lit. })\end{array}$ & $\begin{array}{c}1.84 \\
(2.90)\end{array}$ & $\begin{array}{l}1.80^{\mathrm{ab}} \\
(2.73)\end{array}$ & $\begin{array}{l}1.78^{\mathrm{ab}} \\
(2.67)\end{array}$ & $\begin{array}{l}1.74^{\mathrm{b}} \\
(2.54)\end{array}$ & $\begin{array}{l}1.71^{\mathrm{b}} \\
(2.44)\end{array}$ & $\begin{array}{l}1.62^{\mathrm{b}} \\
(2.13)\end{array}$ & $\begin{array}{l}1.41^{\mathrm{b}} \\
(1.49)\end{array}$ & $690^{\mathrm{b}}$ \\
\hline 5 & $\begin{array}{c}\text { L. lecanii }\left(1 \times 10^{9} \mathrm{cfu} / \mathrm{gm}\right)(40 \mathrm{~g} / 10 \text { lit. }) \text { followed by } \\
\text { L. lecanii }\left(1 \times 10^{9} \mathrm{cfu} / \mathrm{gm}\right)(40 \mathrm{~g} / 10 \text { lit. })\end{array}$ & $\begin{array}{c}1.77 \\
(2.62)\end{array}$ & $\begin{array}{l}1.64^{\mathrm{b}} \\
(2.21)\end{array}$ & $\begin{array}{l}1.64^{\mathrm{b}} \\
(2.19)\end{array}$ & $\begin{array}{r}1.53^{\mathrm{b}} \\
(1.84)\end{array}$ & $\begin{array}{r}1.47^{c} \\
(1.67)\end{array}$ & $\begin{array}{l}1.28^{\mathrm{b}} \\
(1.14)\end{array}$ & $\begin{array}{l}1.20^{\mathrm{b}} \\
(0.95)\end{array}$ & $895^{\mathrm{a}}$ \\
\hline 6 & $\begin{array}{c}\text { L. lecanii }\left(1 \times 10^{9} \mathrm{cfu} / \mathrm{gm}\right)(40 \mathrm{~g} / 10 \text { lit. }) \text { followed by } \\
\text { B. bassiana }\left(1 \times 10^{9} \mathrm{cfu} / \mathrm{gm}\right)(40 \mathrm{~g} / 10 \text { lit. })\end{array}$ & $\begin{array}{c}1.79 \\
(2.71)\end{array}$ & $\begin{array}{l}1.73^{\mathrm{b}} \\
(2.48)\end{array}$ & $\begin{array}{l}1.70^{\mathrm{b}} \\
(2.41)\end{array}$ & $\begin{array}{l}1.67^{\mathrm{b}} \\
(2.28) \\
\end{array}$ & $\begin{array}{l}1.61^{\mathrm{bc}} \\
(2.08)\end{array}$ & $\begin{array}{l}1.53^{\mathrm{b}} \\
(1.86) \\
\end{array}$ & $\begin{array}{l}1.34^{\mathrm{b}} \\
(1.30)\end{array}$ & $768^{\mathrm{ab}}$ \\
\hline 7 & $\begin{array}{c}\text { B. bassiana }\left(1 \times 10^{9} \mathrm{cfu} / \mathrm{gm}\right)(40 \mathrm{~g} / 10 \text { lit. }) \text { followed } \\
\text { by } B \text {. bassiana }\left(1 \times 10^{9} \mathrm{cfu} / \mathrm{gm}\right)(40 \mathrm{~g} / 10 \text { lit. })\end{array}$ & $\begin{array}{c}1.82 \\
(2.81)\end{array}$ & $\begin{array}{l}1.70^{\mathrm{b}} \\
(2.38)\end{array}$ & $\begin{array}{l}1.68^{\mathrm{b}} \\
(2.31)\end{array}$ & $\begin{array}{l}1.64^{\mathrm{b}} \\
(2.18)\end{array}$ & $\begin{array}{l}1.59^{\mathrm{bc}} \\
(2.04)\end{array}$ & $\begin{array}{r}1.53^{\mathrm{b}} \\
(1.85)\end{array}$ & $\begin{array}{l}1.37^{\mathrm{b}} \\
(1.38)\end{array}$ & $737^{\mathrm{ab}}$ \\
\hline 8 & Untreated control & $\begin{array}{c}1.81 \\
(2.79)\end{array}$ & $\begin{array}{c}2.00^{\mathrm{a}} \\
(3.51)\end{array}$ & $\begin{array}{c}2.01^{\mathrm{a}} \\
(3.53)\end{array}$ & $\begin{array}{c}2.01^{\mathrm{a}} \\
(3.56)\end{array}$ & $\begin{array}{c}2.02^{\mathrm{a}} \\
(3.58)\end{array}$ & $\begin{array}{c}2.01^{\mathrm{a}} \\
(3.53)\end{array}$ & $\begin{array}{c}2.01^{\mathrm{a}} \\
(3.56)\end{array}$ & $503^{c}$ \\
\hline & S.Em. \pm & 0.12 & 0.07 & 0.07 & 0.08 & 0.08 & 0.11 & 0.10 & 52.37 \\
\hline & C.D. at $5 \%$ & NS & 0.22 & 0.23 & 0.24 & 0.24 & 0.35 & 0.30 & 159 \\
\hline & C.V. \% & 11.63 & 7.12 & 7.45 & 7.97 & 8.41 & 12.90 & 12.21 & 12.21 \\
\hline
\end{tabular}

*Figures outside the parentheses are $\sqrt{ } \mathrm{x}+0.5$ transformed values, while in parentheses are retransformed value; DAS $=$ Days after spraying. Treatment means with the letter/letters in common are not significant by DNMRT at 5 per cent level of significance.

(30ml/10lit.) (1.89 aphid index). Thetreatment of B. bassiana (40g/10lit.) followed by Azadirachtin 1500ppm (40ml/10lit.) had recorded 2.13 aphid Indexs The aphid population was remained higher in the plots of untreated control had recorded 3.53 aphid index at three days after second spray.

\section{Seven days after second spray}

All the treatments remained significantly superior over untreated control with respect to aphid index at seven days of second spray. The lowest aphid index was recorded in $L$. lecanii (40g/10lit.) followed by L. lecanii (40g/10lit.) (0.95 aphid index) and it was found as the most superior over rest of the treatments, however, it was at par with L. lecanii (40g/10lit.) followed by Azadirachtin 10000ppm (30ml/10lit.) (1.10 aphid index) and $L$. lecanii (40g/10lit.) followed by
Azadirachtin 1500 ppm (40ml/10lit.) (1.17 aphid index), L. lecanii(40g/10lit.) followed by B. bassiana (40 g/10 lit.) had registered 1.30aphid index, B. bassiana (40 g/10 lit.) followed by $B$. bassiana (40g/10lit.) ( 1.38 aphid index). The treatment of $B$. bassiana (40g/10lit.) followed by Azadirachtin 10000 ppm (30ml/10lit.) (1.61aphidindex). B. bassiana (40 g/10 lit.) followed by Azadirachtin 1500ppm (40ml/10lit.) had record 1.49 aphid index. The aphid population was remained higher in the plots of untreated control had recorded 3.56 aphid index at seven days of second spray.

\section{Seed yield of isabgul}

The results on seed yield are presented in Table 2. It can be seen from the data that all the bio-rationals were remained significantly superior over untreated control. The treatment of 
L. lecanii $\left(1 \times 10^{9} \mathrm{cfu} / \mathrm{gm}\right)(40 \mathrm{~g} / 10$ lit.) followed by $L$. lecanii (40g/10lit.) had obtained the highest seed yield of isabgul $\left(895 \mathrm{kgha}^{-1}\right)$, however, it was remained at par with $L$. lecanii (40g/10lit.) followed by Azadirachtin 10000ppm (30ml/10lit.) (827 $\left.\mathrm{kgha}^{-1}\right)$, L. lecanii (40g/10lit.) followed by Azadirachtin 1500 ppm (40ml/10lit.) (814 $\left.\mathrm{kgha}^{-1}\right), \quad$ L. lecanii (40g/10lit.)followed by B. bassiana (40g/10lit.) (768 $\mathrm{kgha}^{-1}$ ) and $B$. bassiana (40g/10lit.) followed byB.bassiana (40g/10lit.) $\left(737 \mathrm{kgha}^{-1}\right)$. Non protected plots of isabgul had obtained $\left(503 \mathrm{kgha}^{-1}\right)$ seed yield of isabgul.

Similar observations were also reported by Upadhyay and Mishra (1999), evaluated Krantineem spray and Neemgold $(0.3$ and $0.5 \%)$ and crude extract of neem seed kernel (1 and $2 \%$ ) along with some conventional insecticides against isabgul aphid, A. gossypii and found that all neem preparations reduced aphid population after 24 hours of spraying, but only 2 per cent crude extract maintained low incidence for more than 24 hours. Efficacy of few bio-rational pesticides against $A$. gossypii on cucumber were evaluated and revealed that garlic, Neemplus and Verticilliumlecanii had 35 and 65 per cent mortality (Razvi et al., 2006) ${ }^{[9]}$. Anitha and Nandihalli (2008) noticed that neem seed kernel extract 5 per cent was effective in controlling aphid on okra followed by neem oil 2 per cent after 15 days of each spray. Neem seed kernel extract recorded highest cost: benefit ratio (18.56). Korat et al. (2008) ${ }^{[6]}$ among the botanical insecticides tested NSKE (5\%) registered minimum population of aphid (7.57 to 8.71 aphids/leaf) and NSKE (5\%) proved to be more effective against aphid infesting okra and was at par with recommended conventional insecticide. Aheibam (2013) evaluated nine bio-pesticides against $A$. gossypii infesting coriander; neem oil $(0.3 \%)$, NeemAzal-T/S $(1 \%)$ and Gronim $(0.30 \%)$ effectively manage the pest. The effectiveness is also reflected on yield of coriander seeds. In the above treatments, yield increase over control ranged from 84.70 to 91.60 per cent, whereas, avoidable losses were up to 3.60 per cent. Patel (2013) ${ }^{[7,8]}$ tested that the Passilomycesfumosoresus @ 1 1/ha was found to be the most effective treatment which was significantly better than all the treatment except Beauveria bassiana@11/ha, followed by Neem soap @ 2.599 kg/ha, which was significantly better than Pongamia soap @ 2.5 $\mathrm{kg} / \mathrm{ha}$, but at par with Verticilliumlecanii @ 1 1/ha and Metarrhiziumanisopliae @ 1 1/ha. Patil and Patel (2013) [7,8] evaluated some chemical and botanical insecticides against Isabgul aphid and revealed that among all the botanical insecticides used, neem oil @ 0.5 per cent was found to be superior over other botanicals and registered maximum (7.21 $\mathrm{q} /$ ha) seed yield.Emami (2016) evaluated some bio-rational insecticides against aphid on cucumber crop revealed that highest mortality in insecticidal soap, surfactant and antifeeding treatments occurred after 3 days, respectively with $78.47,67.16$ and 60.48 per cent mortality, respectively.

\section{References}

1. Aheibam RD. Bionomics of aphid, Aphis gossypiiGlover and its bio-rational management on coriander. M.Sc. (Agri.) Thesis, submitted to B. A. College of Agriculture, Anand Agricultural University,Anand, 2013.

2. Anitha KR. Seasonal incidence and management of sucking pests of okra.M.Sc. (Agri.)Thesis, submitted to the University of Agricultural Sciences, Dharwad, 2007.

3. Anonymous. Director of Horticulture, KrishiBhavan Sector 10-A Gandhinagar, 2016-17.
4. Bank. A method for estimating population and counting large number of aphid, Aphis fabae Scop. Bulletin of Entomological Research. 1954; 45(4):751-756.

5. Emami MS. Bio-efficacy of some bio-rational insecticides for the control of Aphis gossypii Glover on greenhouse cucumber. Actaagriculture Slovenica. 2016; 4(2):419-427.

6. Korat DM, Adilakshmi A, Vaishnav PR. Bio-efficacy of some botanical insecticides against pests of okra. Karnataka Journal of Agriculture Science. 2008; 21(2):290-292.

7. Patel SG. Studies on insect pest complex of brinjal, Solanummelongena (Linn.) and their control with insecticides and bio-pesticides. M.Sc. (Agri.) Thesis, submitted to the Jawaharlal Nehru Krishi Vishwa Vidyalaya, Jabalpur, 2013.

8. Patil SJ, Patel BR. Evaluation of different synthetic and botanical insecticides against aphid, Aphis gossypii Glover infesting isabgul crop.The Bioscan. 2013; 8(2):705-707.

9. Razvi SA, Al-Shidi R, Al-Zidjli NM. Efficacy of certain bio-rational pesticides for the control of aphid (Aphis gossypii Glover) in cucumber. Indian Journal of Plant Protection. 2006; 34(1):19-21.

10. Reddy P. Advances in integrated pest management in horticultural crops. Ornamental, Medicinal, Aromatic and Tuber Crops. 2009; 3:124-128.

11. Trease GE, Evans WC. Pharmacology $11^{\text {th }}$ Ed. Cassell and Coller MacMillan Publishers, London, 1978.

12. Upadhyay S, Mishra RC. Efficacy and economics of insecticides and neem (Azadirachtaindica) based products on incidence of aphid (Aphis gossypii) on isabgul (Plantagoovata). Indian Journal of Agricultural Sciences. 1999; 69(2):161-162. 